\title{
Efek Kausal Konsep Diri Akademik dan Minat Keguruan terhadap Ekspektasi Karier sebagai Guru dan Kaitannya dengan Sikap Profesionalisme Keguruan
}

\author{
I Gede Indra Supriadi ${ }^{1}$, Nyoman Dantes ${ }^{2}$, Ni Ketut Suarni ${ }^{3}$ \\ 1,2,3Pendidikan Dasar, Program Pascasarjana, Universitas Pendidikan Ganesha, Indonesia
}

\section{Keywords:}

academic self-concept;

teaching interest;

career expectation;

teaching professionalism attitude

\begin{abstract}
This research aims at investigating: (1) the direct effect of career expectation as teacher (X3) on teaching professionalism attitude (X4), (2) the direct effect of academic self-concept (X1) on teaching professionalism attitude (X4), (3) the direct effect of teaching interest (X2) on teaching professionalism attitude (X4), (4) the direct effect of academic self-concept (X1) on career expectation as teacher (X3), (5) the direct effect of teaching interest (X2) on career expectation as teacher (X3), (6) the indirect effect of academic selfconcept (X1) on teaching professionalism attitude (X4), (7) the indirect effect of teaching interest (X2) on teaching professionalism attitude (X4). The population of the research was 251 students of PGSD Undiksha. It was an ex-post factor research. The result of the research shows that: (1) there is a direct effect of 0.2971 from X3 on X4, (2) there is a direct effect of 0.2724 from X1 on X4, (3) there is a direct effect of 0.1706 from X2 on X4, (4) there is a direct effect of 0.3709 from X1 on X3, (5) there is a direct effect of 0.2084 from X2 on X3, (6) there is an indirect effect of 0.2496 from $\mathrm{X} 1$ on $\mathrm{X} 4,(7)$ there is an indirect effect of 0.2914 from X2 on X4.
\end{abstract}

\begin{abstract}
Abstrak:Tujuan penelitian ini adalah untuk mengetahui besarnya: (1) efek langsung ekspektasi karier sebagai guru (X3) terhadap sikap profesionalisme keguruan (X4), (2) efek langsung konsep diri akademik (X1) terhadap sikap profesionalisme keguruan (X4), (3) efek langsung minat keguruan (X2) terhadap sikap profesionalisme keguruan (X4), (4) efek langsung konsep diri akademik (X1) terhadap ekspektasi karier sebagai guru (X3), (5) efek langsung minat keguruan (X2) terhadap ekspektasi karier sebagai guru (X3), (6) efek tidak langsung total konsep diri akademik (X1) terhadap sikap profesionalisme keguruan (X4), dan (7) efek tidak langsung total minat keguruan (X2) terhadap sikap profesionalisme keguruan (X4). Populasi penelitian ini adalah mahasiswa jurusan PGSD Undiksha dengan jumlah sampel 251 orang. Penelitian ini berbentuk penelitian ex-post facto. Data dianalisis dengan path analysis. Hasil penelitian menunjukkan bahwa: (1) ada efek langsung sebesar 0,2971 dari X3 terhadap X4, (2) ada efek langsung sebesar 0,2724 dari X1 terhadap X4, (3) ada efek langsung sebesar 0,1706 dari X2 terhadap X4, (4) ada efek langsung sebesar 0,3709 dari X1 terhadap X3, (5) ada efek langsung sebesar 0,2084 dari X2 terhadap X3, (6) ada efek tidak langsung total sebesar 0,2496 dari X1 terhadap X4, (7) ada efek tidak langsung total sebesar 0,2914 dari X2 terhadap X4.
\end{abstract}

Alamat Korespondensi

E-mail: indra.supriadi@pasca.undiksha.ac.id (I Gede Indra Supriadi)

\section{Pendahuluan}

Pendidikan adalah sebuah sistem. Dalam Undang-undang Nomor 20 tahun 2003 pasal 1 ayat 3 disebutkan bahwa sistem pendidikan nasional adalah keseluruhan komponen pendidikan yang saling terkait secara terpadu untuk mencapai tujuan pendidikan nasional. Sejalan dengan hal tersebut, Uno (2010:11) mengatakan bahwa sistem adalah suatu kesatuan unsur-unsur yang saling berinteraksi secara fungsional yang memperoleh masukan menjadi keluaran. Dikaitkan dengan pengertian sistem tersebut, pendidikan merupakan kesatuan dari unsur-unsur seperti peserta didik, guru, kurikulum, media, dan unsur lainnya yang berinteraksi satu sama lain berdasarkan fungsinya masing-masing yang memproses masukan menjadi keluaran. Pendidikan memiliki beberapa subsistem atau unsur-unsur yang masing- 
masing unsurnya tersebut memiliki fungsi yang berbeda, tetapi memiliki suatu tujuan yang sama. Unsur terpenting dalam sistem pendidikan adalah guru.

Pidarta (2007:36) menyatakan, "berhasil atau tidaknya suatu pendidikan sangat ditentukan oleh personalianya".Hal ini jelas menyiratkan secara eksplisit bahwa peran orang-orang yang terlibat dalam sistem pendidikan sangatlah vital. Hasbullah (2006:21) menjelaskan lebih detil tentang unsur yang dimaksud, dengan menyatakan bahwa jabatan guru merupakan pekerjaan mulia dan agung karena guru merupakan ujung tombak untuk mencerdaskan bangsa. Sedemikian penting peran guru dalam pendidikan sehingga kualitas guru merupakan syarat mutlak untuk dapat menciptakan pendidikan yang maksimal.

Berbicara tentang kualitas guru, tidak bisa lepas dari masa-masa pada saat guru menempuh pendidikan di perguruan tinggi sebagai mahasiswa calon guru. Selama proses pendidikan, calon guru mengalami dinamika dan perkembangan baik dalam kemampuan kognitif, afektif, maupun psikomotornya. Proses pembentukan kemampuan mahasiswa calon guru itu sendiri tentunya sangat dipengaruhi oleh kesiapan dari dalam diri mahasiswa untuk berperilaku yang mendukung ketercapaian kemampuan yang diharapkan. Kesiapan dari dalam diri mahasiswa tersebut diterjemahkan sebagai sikap profesionalisme keguruan mahasiwa.Sikap profesionalisme keguruan mahasiswa adalah kesiapan untuk timbulnya suatu tingkah laku yang mencirikan seorang guru yang berkualitas.

Jika dikaji lebih jauh tentang sikap profesionalisme keguruan, maka aspek sikap merupakan hal yang substantif untuk diketahui.Sujanto dkk (2008:42) menyatakan bahwa sikap seringkali didefinisikan sebagai tendensi untuk bereaksi secara menyenangkan ataupun tidak menyenangkan terhadap sekelompok stimuli yang ditunjuk. Dari pendapat tersebut dapat diartikan bahwa sikap merupakan hal yang sangat penting dalam proses pembentukan kualitas seorang calon guru karena berhubungan dengan keseriusan seorang mahasiswa calon guru dalam menjalani proses tersebut karena didasari oleh senang atau tidak senang. Pentingnya unsur sikap juga terlihat dari penelitian Adnyana (2011) dengan judul determinasi kepemimpinan kepala sekolah, pelaksanaan supervisi akademik, dan sikap guru terhadap profesinya dengan kinerja guru matematika SMP negeri di kabupaten Jembrana.Dari penelitian tersebut dapat diketahui bahwa sikap guru terhadap profesinya memiliki hubungan yang signifikan dan positif dengan kinerja guru, sehingga berdasarkan penelitian tersebut dapat diasumsikan bahwa sikap memiliki hubungan positif dengan kinerja, yang mana kinerja itu sendiri merupakan suatu bagian dari perilaku.Maka, hasil penelitian tersebut merupakan penguat bahwa sikap profesionalisme keguruan adalah hal yang sangat penting untuk dimiliki seorang pendidik karena merupakan cikal bakal dari perilaku profesionalisme keguruan.

Sedemikian pentingnya sikap profesionalisme keguruan mahasiswa, sehingga idealnya seluruh mahasiswa calon guru harus memiliki sikap profesionalisme keguruan yang tinggi.Sebagaimana yang dinyatakan oleh Soetjipto dan Raflis Kosasi (2004:54) bahwa pembentukan sikap yang baik tidak mungkin muncul begitu saja, tetapi harus dibina sejak calon guru memulai pendidikannya di lembaga pendidikan guru.Sikap profesionalisme keguruan yang tinggi merupakan modal paling mendasar untuk menciptakan sosok guru yang berkualitas bagi pendidikan.Akan tetapi kenyataan di lapangan belum menunjukkan hal yang senada.Hal ini dapat dilihat dari observasi secara langsung terhadap perilaku mahasiswa yang merupakan salah satu perwujudan sikapnya.Secara umum, perilaku mahasiswa menunjukkan masih banyak kejadian yang merujuk pada adanya keragaman sikap. Jika dilihat dari hasil observasi secara langsung terhadap mahasiswa jurusan pendidikan guru sekolah dasar UNDIKSHA singaraja pada tanggal 4 sampai 6 Juni 2012, ada mahasiswa yang berperilaku tidak disiplin waktu, sering tidak mengumpulkan tugas, sampai pada keterlambatan menyelesaikan studi. Fenomena ini dapat diasumsikan sebagai adanya sikap profesionalisme keguruan yang rendah pada diri mereka.Namun ada pula mahasiswa calon guru yang disiplin waktu, rajin menyelesaikan tugas, mengikuti berbagai lomba, hingga menyelesaikan studi dengan indeks prestasi kumulatif yang tinggi sehingga dapat diasumsikan sebagai adanya sikap profesionalisme keguruan yang tinggi.Keragaman perilaku tersebut menunjukkan bahwa sikap profesionalisme keguruan mahasiswa khususnya mahasiswa calon guru sekolah dasar masih menunjukkan keragaman kualitas. Ini berarti ada mahasiswa calon guru SD yang siap untuk menjadi guru yang berkualitas dan ada juga yang belum siap untuk menjadi guru yang berkualitas. Hal ini tentu saja berbeda dengan yang diharapkan yakni seluruh mahasiswa calon guru khususnya guru sekolah dasar hendaknya memiliki sikap profesionalisme keguruan yang tinggi.

Keberagaman kualitas sikap profesionalisme keguruan mahasiswa PGSD tentunya merupakan sebuah permasalahan.Melihat permasalahan tersebut, perlu pendalaman terhadap hal-hal yang mempengaruhi beragamnya sikap profesionalisme keguruan mahasiswa.Beberapa hal yang mempengaruhi sikap profesionalisme keguruan dapat dikaji dari prinsip-prinsip profesi guru.Dhanim dan Khairil (2010:11) menyatakan bahwa salah satu prinsip profesi guru adalah memiliki minat, panggilan jiwa, dan idealisme.Hal ini berarti bahwa minat, panggilan jiwa, dan idealisme adalah suatu dasar yang dapat menimbulkan dan menumbuh-kembangkan profesionalisme keguruan. 
Minat adalah suatu dorongan yang menyebabkan terikatnya perhatian individu pada objek tertentu seperti pekerjaan, pelajaran, benda, dan orang (Jahja, 2011:63). Hal ini sesuai dengan pernyataan Srijanti dan Artiningrum (2006:29) bahwa minat secara psikologis dapat diartikan sebagai usaha untuk mempelajari dan mencari sesuatu. Thorndike (1997:308) menyatakan "interest test provide information about a person's general pattern of likes and dislikes". Interest yang dalam bahasa Indonesia berarti minat tersebut oleh Thordike dikatakan merujuk pada suka dan tidak sukanya individu pada suatu hal. Pendapat-pendapat tersebut menyatakan dengan jelas bahwa minat menjadi hal yang sangat penting dalam mendorong keterikatan perhatian individu.Dalam konteks ini, bidang keguruan adalah objek yang dituju sehingga aspek pertama yang dapat menjadi penyebab sikap profesionalisme keguruan mahasiswa adalah minat keguruan.

Terkait dengan hal lain yang dapat mempengaruhi sikap profesionalisme keguruan, sebagaimana yang dinyatakan dalam prinsip profesionalisme guru, panggilan jiwa dan idealisme adalah hal yang harus dimiliki seorang guru profesionalisme. Panggilan jiwa dan idealisme mengacu pada konsep diri dan ekspektasi karier sebagai guru seorang mahasiswa calon guru.

Slamento (2010:182) menyatakan bahwa konsep diri adalah persepsi keseluruhan yang dimiliki seseorang mengenai dirinya sendiri.Hal ini berarti konsep diri merupakan tanggapan atas dirinya sendiri.Konsep diri menurut Sarwono \& Meinarno (2009:53) merupakan kesadaran seseorang mengenai siapa dirinya.Hal ini berarti konsep diri adalah suatu kemengertian tentang dirinya sendiri.Konsep diri menurut Agustiani (2009: 138) adalah gambaran yang dimiliki seseorang tentang dirinya, yang dibentuk melalui pengalaman-pengalaman yang diperoleh dari interaksi dengan lingkungan.Hal ini berarti konsep diri sebenarnya terbentuk melalui pengalaman dan interaksi dengan lingkungannya.

Senada dengan beberapa pengertian tersebut, Djaali (2008:129) menyatakan bahwa konsep diri adalah pandangan seseorang tentang dirinya sendiri yang menyangkut apa yang ia ketahui dan rasakan tentang perilakunya, isi pikiran dan perasaannya, serta bagaimana perilakunya tersebut berpengaruh terhadap orang lain. Definisi Djaali selain mengungkapkan bahwa konsep diri merupakan cara pandang terhadap dirinya sendiri, juga menjelaskan secara lebih rinci bahwa pandangan terhadap dirinya tersebut terdiri dari perilakunya, isi pikiran dan perasaannya, serta bagaimana perilakunya tersebut berpengaruh terhadap orang lain. Dari beberapa pendapat tersebut, konsep diri mengacu pada gambaran diri untuk menjadi manusia yang diharapkan.Hal ini sangat erat kaitannya dengan sikap yang dapat dibentuk dari gambaran diri ini untuk menjadi manusia yang diharapkan tersebut.Gambaran diri dalam konteks sikap profesionalisme keguruan tentunya berada pada wilayah akademis sehingga hal yang dapat mempengaruhi sikap profesionalisme keguruan tersebut adalah gambaran diri terhadap kemampuan akademis dan keberhasilan di sekolah yang dapat disebut dengan konsep diri akademik.

Unsur lain yang dapat menjadi penyebab sikap profesionalisme keguruan adalah ekspektasi kariernya sebagai guru. Ekspektasi karier guru adalah harapan akan pekerjaan atau jabatan sebagai guru yang dipegang selama masa kerja seseorang. Hal ini dikuatkan oleh pernyataan Srijanti dan Artiningrum (2006:24) yang menyebut pekerjaan dan minat yang selaras akan menjadi penyebab suksesnya hidup. Dalam kehidupan, tentunya seorang mahasiswa menginginkan kesuksesan dalam hidupnya sehingga harapan akan karier itu sendiri dapat mempengaruhi sikap profesionalisme keguruannya.Untuk mengetahui bagaimana pengaruh konsep diri akademik, minat keguruan, dan ekspektasi karier sebagai guru terhadap sikap profesionalisme keguruan tersebut, serta pengaruh konsep diri akademik dan minat keguruan terhadap ekspektasi karier, maka dilakukan penelitian untuk mengetahuinya.

\section{Metode}

Penelitian ini adalah penelitian Ex-post facto jenis penelitian kausal komparatif atau disebut juga hubungan sebab akibat. Menurut Sukardi (2009:171), penelitian kausal komparatif sebagai penelitian Expost facto karena dalam penelitian itu variabel juga telah terjadi dan peneliti tidak berusaha memanipulasi dan mengontrolnya. Pada penelitian kausal komparatif, variabel penyebab dan variabel yang dipengaruhi telah terjadi dan diselidiki lagi dengan cara merunut kembali. Dalam penelitian ini, populasinya adalah mahasiswa jurusan Pendidikan Guru Sekolah Dasar Universitas Pendidikan Ganesha Singaraja yang berjumlah 852 orang yang terdiri dari 305 orang mahasiswa laki-laki dan 547 orang mahasiswa perempuan. Dari populasi tersebut, pengambilan sampel dilakukan dengan tehnik proportionate stratified random sampling dan dipilih sampel sebanyak 251 orang mahasiswa dari empat tingkatan semester terdiri dari 90 orang mahasiswa laki-laki dan 161 orang mahasiswa perempuan yang diambil secara acak. Tehnik kuisioner dipakai sebagai pengumpul data utama. Menurut Sugiyono (2012:199), kuisioner merupakan tehnik pengumpulan data yang dilakukan dengan cara memberi seperangkat pertanyaan atau pernyataan tertulis kepada responden untuk dijawabnya. Sudjana (1989:70) mengatakan bahwa kuisioner memiliki kelebihan yakni sifatnya praktis, hemat waktu, tenaga, dan biaya. Sedangkan kelemahannya adalah jawaban sering tidak objektif, lebih-lebih bila pertanyaannya kurang 
tajam yang memungkinkan siswa berpura-pura. Untuk mengatasi kelemahan tersebut, disusun butir-butir pertanyaan kuisioner yang tajam serta diciptakan suasana tes yang kondusif melalui pengarahan kepada sampel sebelum tes dilaksanakan, guna menghindari adanya jawaban yang tidak objektif dan berpurapura.Tehnik observasi dalam penelitian ini dipakai sebagai tehnik pelengkap dalam pengumpulan data awal. Skala pengukuran yang dipakai adalah skala Likert dengan data yang diukur adalah data hasil pengukuran gejala psikologi. Menurut Candiasa (2010:8) data hasil pengukuran gejala psikologi dianggap sebagai data interval karena bersifat kontinyu.

Pengembangan instrumen dilakukan berdasarkan kajian teori. Dari dasar teori yang terdiri dari definisi dan dimensi masing-masing variabel selanjutnya dihasilkan indikator, yang disusun dalam bentuk kisi-kisi instrumen. Berdasarkan kisi-kisi instrumen maka disusun butir-butir instrumen masingmasing variabel. Selanjutnya untuk menentukan validitas isi (content validity) dilakukan validasi dengan meminta pendapat ahli. Dari uji validitas isi, instrumen dinyatakan valid dari segi isi dengan rata-rata nilai validitas isi 1 untuk masing-masing instrumen. Selanjutnya validasi diteruskan dengan uji coba instrumen untuk mengetahui validitas butir dan reliabilitas instrumen. Dari hasil analisis, validitas butir rata-rata pada instrumen sikap profesionalisme keguruan adalah 0,472, ekspektasi karier sebagai guru 0,486 , konsep diri akademik 0,494 , dan minat keguruan 0,61 . Sejumlah butir yang dinyatakan tidak valid tidak dipakai dalam instrumen penelitian, sedangkan butir yang valid dipakai dan dilanjutkan pada pengujian reliabilitas masing-masing instrumen. Uji reliabilitas yang dilakukan dengan tehnik reliabilitas belah dua mendapatkan hasil bahwa instrumen dinyatakan sudah reliabel dengan angka reliabilitas instrumen sikap profesionalisme keguruan 0,760, ekspektasi karier sebagai guru 0,912, konsep diri akademik 0,858, dan minat keguruan 0,899. Dari hasil uji validitas dan reliabilitas tersebut, maka masingmasing instrumen dapat digunakan untuk penelitian.

Penelitian ini menggunakan beberapa tehnik analisis data. Untuk uji prasyarat analisis digunakan uji normalitas sebaran data, uji linieritas, dan uji multikolinieritas. Dari hasil uji prasyarat analisis, diketahui bahwa data berdistribusi normal (bilangan signifikansi Kolmogorov Smirnov x1 $=0,059, \mathrm{x} 2=$ $0,200, x 3=0,200$, dan $x 4=0,200$ ). Bentuk regresi linier (sig. dari $F$ deviation from linearity $x 1-x 3=0,387$, $\mathrm{x} 2-\mathrm{x} 3=0,079, \mathrm{x} 1-\mathrm{x} 4=0,184, \mathrm{x} 2-\mathrm{x} 4=0,667, \mathrm{x} 3-\mathrm{x} 4=0,271$ ). Tidak terjadi multikolinieritas (tolerance $\mathrm{x} 1-\mathrm{x} 3$ $=0,639, \mathrm{x} 2-\mathrm{x} 3=0,639, \mathrm{x} 1-\mathrm{x} 4=0,570, \mathrm{x} 2-\mathrm{x} 4=0,616, \mathrm{x} 3-\mathrm{x} 4=0,727, \mathrm{VIF} \mathrm{x} 1-\mathrm{x} 3=1,564, \mathrm{x} 2-\mathrm{x} 3=1,564, \mathrm{x} 1-\mathrm{x} 4$ $=1,753, \mathrm{x} 2-\mathrm{x} 4=1,624, \mathrm{x} 3-\mathrm{x} 4=1,376$ ).Dalam penelitian ini digunakan analisis jalur (path analysis) untuk menguji hipotesis penelitian. Menurut Koyan (2012:171) analisis jalur merupakan suatu metode yang digunakan pada model kausal yang telah dirumuskan peneliti atas dasar pertimbangan teoritis dan pengetahuan tertentu. Jadi menurut Koyan, analisis jalur memiliki daya guna untuk mencek atau menguji kausal yang telah diteorikan dan bukan untuk menurunkan teori kausal tersebut. Langkah-langkah dari penggunaan analisis jalur (path analysis) dimulai dari menentukan diagram jalur berdasarkan landasan teori, menentukan sistem rekursif, menghitung koefisien korelasi antar variabel, dan menghitung koefisien jalur.

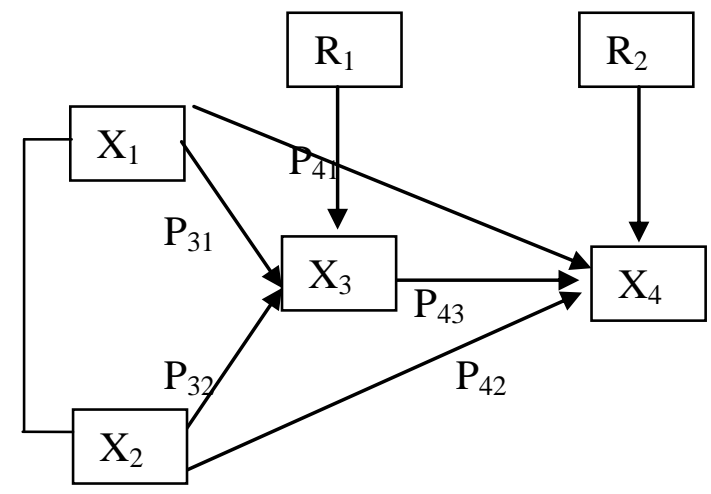

Keterangan:

Gambar 1. Diagram jalur

X1 : Konsep diri akademik

X2 : Minat keguruan

X3 : Ekspektasi karier sebagai guru

X4 : Sikap profesionalisme keguruan

R1 : Residual pada variabel X3

R2 : Residual pada variabel X4

P31 : Koefisien jalur dari X1 ke X3 
P32 : Koefisien jalur dari X2 ke X3

P41 : Koefisien jalur dari X1 ke X4

P42 : Koefisien jalur dari X2 ke X4

P43 : Koefisien jalur dari X3 ke X4

\section{Hasil dan Pembahasan}

Hasil penelitian berupa data skor semua variabel dapat dijelaskan dalam tabel sebagai berikut.

Tabel 1. Tabel distribusi data hasil penelitian

\begin{tabular}{|c|c|c|c|c|c|c|c|}
\hline \multicolumn{2}{|c|}{$\mathrm{X}_{4}$} & \multicolumn{2}{|c|}{$\mathbf{X}_{3}$} & \multicolumn{2}{|c|}{$\mathbf{X}_{1}$} & \multicolumn{2}{|c|}{$\mathbf{X}_{2}$} \\
\hline Skor & $\mathrm{f}$ & Skor & $\mathrm{f}$ & Skor & $\mathrm{f}$ & Skor & $\mathrm{f}$ \\
\hline $113-118$ & 2 & $80-84$ & 1 & $121-125$ & 3 & $107-110$ & 4 \\
\hline $119-124$ & 3 & $85-89$ & 1 & $126-130$ & 7 & $111-114$ & 4 \\
\hline $125-130$ & 8 & $90-94$ & 9 & $131-135$ & 7 & $115-118$ & 15 \\
\hline $131-136$ & 11 & $95-99$ & 16 & $136-140$ & 16 & $119-122$ & 24 \\
\hline $137-142$ & 35 & $100-104$ & 28 & $141-145$ & 26 & $123-126$ & 26 \\
\hline $143-148$ & 42 & $105-109$ & 39 & $146-150$ & 43 & $127-130$ & 35 \\
\hline $149-154$ & 52 & $110-114$ & 57 & $151-155$ & 40 & $131-134$ & 44 \\
\hline $155-160$ & 48 & $115-119$ & 40 & $156-160$ & 34 & $135-138$ & 37 \\
\hline $161-166$ & 27 & $120-124$ & 35 & $161-165$ & 37 & $139-142$ & 28 \\
\hline $167-172$ & 18 & $125-129$ & 21 & $166-170$ & 23 & $143-146$ & 26 \\
\hline $173-178$ & 5 & $130-134$ & 4 & $171-175$ & 15 & $147-151$ & 8 \\
\hline
\end{tabular}

Skor sikap profesionalisme keguruan sebagaimana ditampilkan dalam tabel 1, memiliki rerata 150,66 yang terletak pada kelas interval 149 - 154. Skor ekspektasi karier sebagai guru memiliki rerata 111,92 yang terletak pada kelas interval 110 - 114. Skor konsep diri akademik memiliki rerata 153,12 yang terletak pada kelas interval 151 - 155. Skor minat keguruan memiliki rerata 131,22 yang terletak pada kelas interval 131 - 134. Dari data tersebut, diperoleh beberapa hasil sebagai berikut. Pertama, P43 $=0,2971$, menunjukkan bahwa koefisien jalur X3 terhadap X4 lebih dari taraf signifikansi $(0,05)$ sehingga dapat disimpulkan bahwa variabel X3 memiliki efek langsung yang signifikan terhadap variabel X4. Kedua, P41 = 0,2724, menunjukkan bahwa koefisien jalur X1 terhadap X4 lebih dari taraf signifikansi $(0,05)$ sehingga dapat disimpulkan bahwa variabel X1 memiliki efek langsung yang signifikan terhadap variabel X4. Ketiga, P42 = 0,1706, menunjukkan bahwa koefisien jalur X2 terhadap X4 lebih dari taraf signifikansi $(0,05)$ sehingga dapat disimpulkan bahwa variabel X2 memiliki efek langsung yang signifikan terhadap variabel X4. Keempat, P31 = 0,3709, menunjukkan bahwa koefisien jalur X1 terhadap X3 lebih dari taraf signifikansi $(0,05)$ sehingga dapat disimpulkan bahwa variabel X1 memiliki efek langsung yang signifikan terhadap variabel X3. Kelima, P32 = 0,2084, menunjukkan bahwa koefisien jalur X2 terhadap X3 lebih dari taraf signifikansi $(0,05)$ sehingga dapat disimpulkan bahwa variabel X2 memiliki efek langsung yang signifikan terhadap variabel X3. Keenam, P41 =0,2724 dan r14=0,522, maka efek tidak langsung total X1 terhadap X4 melalui X3 = r14- P41 = 0,522 - 0,2724 =0,2496. Hal ini menunjukkan bahwa efek tidak langsung total X1 terhadap X4 melalui X3, lebih dari taraf signifikansi $(0,05)$ sehingga dapat disimpulkan bahwa variabel X1 memiliki efek tidak langsung yang signifikan terhadap variabel X4 melalui X3. Ketujuh, P42 = 0,1706 dan r24 = 0,462, maka efek tidak langsung total X2 terhadap X4 melalui X3 = r24- P42= $0,462-0,1706=0,2914$. Hal ini menunjukkan bahwa efek tidak langsung total X2 terhadap X4 melalui X3, lebih dari taraf signifikansi $(0,05)$ sehingga dapat disimpulkan bahwa variabel X2 memiliki efek tidak langsung yang signifikan terhadap variabel X4 melalui X3.

Sesuai dengan angka indeks korelasi product moment antar variabel, dapat dihasilkan koefisien determinan yang menunjukkan kontribusi suatu variabel eksogen terhadap variabel endogen, yaitu: (1) kontribusi X3 terhadap X4 = 25,80\%, (2) kontribusi X1 terhadap X4 = 27,24\%, (3) kontribusi X2 terhadap X4 = 21,34\%, (4) kontribusi X1 terhadap X3 = 24,60\%, (5) kontribusi X2 terhadap X3 = 18,57\%. Sesuai dengan hasil uji hipotesis dari tujuh hipotesis yang diajukan, maka dapat dibahas sebagai berikut.

Hubungan antara variabel ekspektasi karier sebagai guru (X3) dengan variabel sikap profesionalisme keguruan (X4) memiliki koefisien jalur sebesar 0,2971 yang berarti merupakan efek langsung yang signifikan serta kontribusi X3 terhadap X4 adalah sebesar 25,80\%. Hal ini dapat dijelaskan dari adanya harapan individu akan suatu perkembangan jabatan atau pekerjaan dalam hidupnya. Bila harapannya tinggi akan perkembangan dan kemajuan dalam pekerjaannya sebagai guru yang notabene tugasnya adalah mendidik, mengajar, membimbing, mengarahkan, melatih, menilai, dan mengevaluasi peserta didik, maka individu tersebut akan berusaha untuk melakukan segala sesuatu agar harapannya itu terwujud. Harapan tinggi untuk menjalani karir sebagai guru akan mengarahkan individu tersebut pada 
hal-hal yang dapat mendukungnya untuk mewujudkan kariernya tersebut. Harapan yang tinggi untuk berkarier sebagai guru yang tugasnya berkaitan dengan peraturan perundang-undangan guru, organisasi profesi, teman sejawat, anak didik, tempat kerja, dan pemimpinnya, akan membuatnya memiliki kecenderungan tinggi pula yang relatif menetap untuk bereaksi dengan cara baik terhadap peraturan perundang-undangan, bereaksi dengan baik terhadap organisasi profesi, bereaksi dengan baik terhadap teman sejawat, bereaksi dengan baik terhadap anak didik, bereaksi dengan baik terhadap tempat kerja, dan bereaksi dengan baik terhadap pemimpin yang secara keseluruhan disebut dengan sikap profesionalisme keguruan. Akan tetapi bila harapan akan perkembangan dan kemajuan dalam pekerjaannya sangat kurang untuk menjadi guru dan melakukan tugas-tugas guru, maka individu tersebut tidak akan berusaha keras untuk menjadi guru yang baik. Harapan yang kecil untuk menjalani karir sebagai guru tidak akan mengarahkan individu tersebut pada hal-hal yang dapat mendukungnya untuk mewujudkan dirinya menjadi seorang guru. Kecilnya harapan akan karier sebagai guru yang tugasnya berkaitan dengan peraturan perundang-undangan, organisasi profesi, teman sejawat, anak didik, tempat kerja, dan pemimpinnya, akan membuatnya memiliki kecenderungan yang relatif menetap untuk bereaksi dengan cara kurang baik atau kurang semestinya terhadap peraturan perundang-undangan, organisasi profesi, teman sejawat, anak didik, tempat kerja, dan pemimpinnya yang secara keseluruhan disebut sikap profesionalisme keguruan. Dari penjelasan tersebut pada akhirnya jelas bahwa ekspektasi karier sebagai guru memiliki efek langsung yang signifikan sebagai penyebab munculnya sikap profesionalisme keguruan.

Hubungan antara variabel konsep diri akademik (X1) dengan variabel sikap profesionalisme keguruan (X4) memiliki koefisien jalur sebesar 0,2724 yang merupakan efek langsung dengan kontribusi X1 terhadap X4 adalah sebesar 27,24\%. Hal ini dapat dijelaskan dari adanya pandangan individu tentang dirinya sendiri. Bila pandangan individu positif tentang dirinya sendiri, yang menyangkut perilakunya, isi pikiran dan perasaannya, yang ditandai dengan menganggap bahwa dirinya mampu berprestasi secara akademik, dihargai oleh teman-temannya, merasa nyaman berada di lingkungan tempat belajarnya, menghargai orang yang memberi ilmu kepadanya, tekun dalam mempelajari segala hal, dan bangga akan prestasi yang diraihnya, maka hal ini akan mengarahkannya pada suatu hal yang sesuai dengan pandangan tentang dirinya tersebut yaitu mempertahankan pandangan positif tersebut. Usaha untuk mempertahankan pandangan positif tersebut dalam dunia pendidikan calon guru akan mengarahkannya pada suatu kecenderungan yang relatif menetap untuk bereaksi dengan cara baik terhadap peraturan perundang-undangan, bereaksi dengan baik terhadap organisasi profesi, bereaksi dengan baik terhadap teman sejawat, bereaksi dengan baik terhadap anak didik, bereaksi dengan baik terhadap tempat kerja, dan bereaksi dengan baik terhadap pemimpin, sebagaimana yang diarahkan dalam pendidikan calon guru yang secara keseluruhan disebut dengan sikap profesionalisme keguruan. Akan tetapi bila pandangan individu negatif tentang dirinya sendiri, yang menyangkut perilakunya, isi pikiran dan perasaannya, yang ditandai dengan yang ditandai dengan menganggap bahwa dirinya kurang mampu berprestasi secara akademik, kurang dihargai oleh teman-temannya, kurang merasa nyaman berada di lingkungan tempat belajarnya, kurang menghargai orang yang memberi ilmu kepadanya, kurang tekun dalam mempelajari segala hal, dan kurang bangga akan prestasi yang diraihnya, maka hal ini akan mengarahkannya pada suatu hal yang sesuai pula dengan pandangan tentang dirinya tersebut yaitu mempertahankan pandangan negatif tersebut. Usaha untuk mempertahankan pandangan negatif tersebut dalam dunia pendidikan akan mengarahkannya pada suatu kecenderungan yang relatif menetap untuk bereaksi dengan cara kurang baik atau kurang semestinya terhadap peraturan perundang-undangan, organisasi profesi, teman sejawat, anak didik, tempat kerja, dan pemimpin. Dari penjelasan tersebut pada akhirnya jelas bahwa konsep diri akademik memiliki efek langsung yang signifikan sebagai penyebab munculnya sikap profesionalisme keguruan.

Hubungan antara variabel minat keguruan (X2) dengan variabel sikap profesionalisme keguruan (X4) memiliki koefisien jalur sebesar 0,1706 yang merupakan efek langsung dengan kontribusi X2 terhadap X4 adalah sebesar 21,34\%. Hal ini dapat dijelaskan mulai dari adanya minat yang merupakan rasa lebih suka dan rasa keterikatan individu pada suatu hal atau aktivitas, tanpa ada yang menyuruh. Apabila mahasiswa memiliki minat tinggi terhadap dunia keguruan atau secara mendetail memiliki ketertarikan tinggi terhadap tugas mendidik, mengajar, membimbing, melatih, dan mengevaluasi peserta didik, maka individu tersebut akan berusaha melakukannya dengan baik. Hal ini disebabkan oleh keinginan setiap individu untuk melakukan dengan baik apa yang menjadi minatnya. Mahasiswa yang memiliki minat keguruan tinggi akan tertarik untuk bisa mendidik dengan baik, bisa mengajar dengan maksimal, bisa membimbing peserta didik ke arah yang diharapkan, bisa melatih peserta didik untuk hidup seperti yang diharapkan, dan bisa mengevaluasi ataupun memutuskan apakah peserta didik sudah berhasil atau tidak dalam belajar. Keinginan untuk dapat melaksanakan minatnya itu dengan baik akan mengarahkan individu pada suatu kecenderungan yang relatif menetap untuk bereaksi dengan cara baik 
juga terhadap peraturan perundang-undangan, bereaksi dengan baik terhadap organisasi profesi, bereaksi dengan baik terhadap teman sejawat, bereaksi dengan baik terhadap anak didik, bereaksi dengan baik terhadap tempat kerja, dan bereaksi dengan baik terhadap pemimpin yang secara keseluruhan disebut dengan sikap profesionalisme keguruan. Akan tetapi bila mahasiswa memiliki minat keguruan yang rendah, maka ketertarikan terhadap dunia keguruan akan kecil sehingga kecil pula keinginan untuk mendidik, mengajar, membimbing, melatih, dan mengevaluasi peserta didik dengan baik. Tidak adanya keinginan untuk dapat melaksanakan kegiatan keguruan itu dengan baik akan mengarahkan individu pada suatu kecenderungan yang relatif menetap untuk bereaksi dengan cara kurang baik atau kurang semestinya terhadap peraturan perundang-undangan, organisasi profesi, teman sejawat, anak didik, tempat kerja, dan pemimpin. Dari penjelasan tersebut pada akhirnya jelas bahwa minat keguruan memiliki efek langsung yang signifikan sebagai penyebab munculnya sikap profesionalisme keguruan.

Hubungan antara variabel konsep diri akademik (X1) dengan variabel ekspektasi karier sebagai guru (X3) memiliki koefisien jalur sebesar 0,3709 yang merupakan efek langsung dengan kontribusi X1 terhadap X3 adalah sebesar $24,60 \%$. Hal ini dapat dijelaskan mulai dari adanya pandangan individu tentang dirinya sendiri. Bila pandangan individu positif tentang dirinya sendiri, yang menyangkut perilakunya, isi pikiran dan perasaannya, dalam dunia akademik pendidikan calon guru, maka hal ini akan mengarahkannya pada suatu harapan yang kuat untuk mewujudkan konsep diri positif itu dalam suatu perkembangan jabatan atau pekerjaan sebagai guru. Tetapi bila pandangan individu negatif tentang dirinya sendiri, yang menyangkut perilakunya, isi pikiran dan perasaannya dalam dunia akademis pendidikan calon guru, maka hal ini akan mengarahkannya pada suatu harapan yang lemah untuk mewujudkan konsep diri itu dalam suatu perkembangan jabatan atau pekerjaan sebagai guru. Dari penjelasan tersebut pada akhirnya jelas bahwa konsep diri akademik memiliki efek langsung yang signifikan sebagai penyebab munculnya ekspektasi karier sebagai guru.

Hubungan antara variabel minat keguruan (X2) dengan variabel ekspektasi karier sebagai guru (X3) memiliki koefisien jalur sebesar 0,2084 yang merupakan efek langsung dengan kontribusi X2 terhadap X3 adalah sebesar 18,57\%. Hal ini dapat dijelaskan mulai dari adanya minat yang merupakan rasa lebih suka dan rasa keterikatan pada suatu hal atau aktivitas, tanpa ada yang menyuruh pasti dimiliki oleh setiap manusia termasuk mahasiswa calon guru. Apabila mahasiswa memiliki minat yang kuat terhadap dunia keguruan atau secara mendetail memiliki minat terhadap tugas mendidik, mengajar, membimbing, melatih, dan mengevaluasi peserta didik, maka individu tersebut akan memiliki harapan yang kuat atau ekspektasi tinggi untuk mewujudkan hal itu dalam suatu perkembangan jabatan atau pekerjaan dalam hidupnya. Sedangkan apabila mahasiswa memiliki minat yang lemah terhadap dunia keguruan atau secara mendetail memiliki minat terhadap tugas mendidik, mengajar, membimbing, melatih, dan mengevaluasi peserta didik, maka individu tersebut akan memiliki harapan yang lemah atau ekspektasi rendah untuk mewujudkan hal itu dalam suatu perkembangan jabatan atau pekerjaan guru dalam hidupnya. Dari penjelasan tersebut jelas bahwa minat keguruan memiliki efek langsung yang signifikan sebagai penyebab munculnya ekspektasi karier sebagai guru.

Hubungan konsep diri akademik (X1) dengan sikap profesionalisme keguruan (X4) memiliki efek tidak langsung total sebesar 0,2496 melalui variabel ekspektasi karier sebagai guru (X3). Hal ini dapat dijelaskan mulai dari adanya pandangan individu tentang dirinya sendiri. Bila pandangan individu positif tentang dirinya sendiri, yang menyangkut perilakunya, isi pikiran dan perasaannya, dalam dunia akademik pendidikan calon guru, maka hal ini akan mengarahkannya pada suatu harapan yang kuat untuk mewujudkan konsep diri positif itu dalam suatu perkembangan jabatan atau pekerjaan sebagai guru. Harapan yang tinggi akan perkembangan dan kemajuan dalam pekerjaannya sebagai guru yang notabene tugasnya adalah mendidik, mengajar, membimbing, mengarahkan, melatih, menilai, dan mengevaluasi peserta didik, maka individu tersebut akan berusaha untuk melakukan segala sesuatu agar harapannya itu terwujud. Harapan tinggi untuk menjalani karir sebagai guru akan mengarahkan individu tersebut pada hal-hal yang dapat mendukungnya untuk mewujudkan kariernya tersebut. Harapan yang tinggi untuk berkarier sebagai guru yang tugasnya berkaitan dengan peraturan perundang-undangan guru, organisasi profesi, teman sejawat, anak didik, tempat kerja, dan pemimpinnya, akan membuatnya memiliki kecenderungan tinggi pula yang relatif menetap untuk bereaksi dengan cara baik terhadap peraturan perundang-undangan, bereaksi dengan baik terhadap organisasi profesi, bereaksi dengan baik terhadap teman sejawat, bereaksi dengan baik terhadap anak didik, bereaksi dengan baik terhadap tempat kerja, dan bereaksi dengan baik terhadap pemimpin yang secara keseluruhan disebut dengan sikap profesionalisme keguruan. Tetapi bila pandangan individu negatif tentang dirinya sendiri dengan kata lain konsep diri akademiknya rendah, yang menyangkut perilakunya, isi pikiran dan perasaannya dalam dunia akademis pendidikan calon guru, maka hal ini akan mengarahkannya pada suatu harapan yang lemah untuk mewujudkan konsep diri itu dalam suatu perkembangan jabatan atau pekerjaan sebagai guru. Kecilnya harapan akan karier sebagai guru yang tugasnya berkaitan dengan peraturan perundang- 
undangan, organisasi profesi, teman sejawat, anak didik, tempat kerja, dan pemimpinnya, membuatnya memiliki kecenderungan yang relatif menetap untuk bereaksi dengan cara kurang baik atau kurang semestinya terhadap peraturan perundang-undangan, organisasi profesi, teman sejawat, anak didik, tempat kerja, dan pemimpinnya yang secara keseluruhan disebut sikap profesionalisme keguruan. Dari penjelasan tersebut jelas bahwa konsep diri akademik memiliki efek tidak langsung yang signifikan pula sebagai penyebab munculnya sikap profesionalisme keguruan melalui ekspektasi karier sebagai guru.

Hubungan minat keguruan (X2) dengan sikap profesionalisme keguruan (X4) memiliki efek tidak langsung total sebesar 0,2914 melalui variabel ekspektasi karier sebagai guru (X3). Hal ini dapat dijelaskan mulai dari adanya minat yang merupakan rasa lebih suka dan rasa keterikatan pada suatu hal atau aktivitas, tanpa ada yang menyuruh pasti dimiliki oleh setiap manusia termasuk mahasiswa calon guru. Apabila mahasiswa memiliki minat yang kuat terhadap dunia keguruan atau secara mendetail memiliki minat terhadap tugas mendidik, mengajar, membimbing, melatih, dan mengevaluasi peserta didik, maka individu tersebut akan memiliki harapan yang kuat atau ekspektasi tinggi untuk mewujudkan hal itu dalam suatu perkembangan jabatan atau pekerjaan guru dalam hidupnya. Harapan yang tinggi akan perkembangan dan kemajuan dalam pekerjaannya sebagai guru yang notabene tugasnya adalah mendidik, mengajar, membimbing, mengarahkan, melatih, dan mengevaluasi peserta didik, membuat individu tersebut berusaha untuk melakukan segala sesuatu agar harapannya itu terwujud. Harapan tinggi untuk menjalani karir sebagai guru akan mengarahkan individu tersebut pada hal-hal yang dapat mendukungnya untuk mewujudkan kariernya tersebut. Harapan yang tinggi untuk berkarier sebagai guru yang tugasnya berkaitan dengan peraturan perundang-undangan guru, organisasi profesi, teman sejawat, anak didik, tempat kerja, dan pemimpinnya, akan membuatnya memiliki kecenderungan tinggi pula yang relatif menetap untuk bereaksi dengan cara baik terhadap peraturan perundang-undangan, bereaksi dengan baik terhadap organisasi profesi, bereaksi dengan baik terhadap teman sejawat, bereaksi dengan baik terhadap anak didik, bereaksi dengan baik terhadap tempat kerja, dan bereaksi dengan baik terhadap pemimpin yang secara keseluruhan disebut dengan sikap profesionalisme keguruan. Sedangkan apabila minat individu lemah terhadap dunia keguruan atau secara mendetail memiliki minat rendah terhadap tugas mendidik, mengajar, membimbing, melatih, dan mengevaluasi peserta didik, maka individu tersebut akan memiliki harapan yang lemah atau ekspektasi rendah untuk mewujudkan hal itu dalam suatu perkembangan jabatan atau pekerjaan guru dalam hidupnya. Kecilnya harapan akan karier sebagai guru yang tugasnya berkaitan dengan peraturan perundang-undangan, organisasi profesi, teman sejawat, anak didik, tempat kerja, dan pemimpinnya, membuatnya memiliki kecenderungan yang relatif menetap untuk bereaksi dengan cara kurang baik atau kurang semestinya terhadap peraturan perundang-undangan, organisasi profesi, teman sejawat, anak didik, tempat kerja, dan pemimpinnya yang secara keseluruhan disebut sikap profesionalisme keguruan. Dari penjelasan tersebut jelas bahwa minat keguruan memiliki efek tidak langsung yang signifikan pula sebagai penyebab munculnya sikap profesionalisme keguruan melalui ekspektasi karier sebagai guru.

\section{Simpulan}

Berdasarkan temuan-temuan dalam penelitian ini, maka disimpulkan beberapa hal sebagai berikut. Efek langsung yang signifikan dari ekspektasi karier sebagai guru terhadap sikap profesionalisme keguruan sebesar 0,2971 dengan kontribusi 25,80\%, menunjukkan bahwa semakin besar ekspektasi karier sebagai guru maka semakin besar pula sikap profesionalisme keguruan. Sebaliknya, semakin kecil ekspektasi karier sebagai guru maka semakin kecil pula sikap profesionalisme keguruan.

Efek langsung yang signifikan dari konsep diri akademik terhadap sikap profesionalisme keguruan sebesar 0,2724 dengan kontribusi 27,24\% menunjukkan bahwa semakin besar konsep diri akademik maka semakin besar pula sikap profesionalisme keguruan. Sebaliknya, semakin kecil konsep diri akademik maka semakin kecil pula sikap profesionalisme keguruan. Selain itu, Efek tidak langsung yang signifikan dari konsep diri akademik terhadap sikap profesionalisme keguruan melalui ekspektasi karier sebagai guru sebesar 0,2496 menunjukkan bahwa semakin besar konsep diri akademik maka semakin besar pula ekspektasi kariernya sebagai guru sehingga berujung pada semakin besarnya sikap profesionalisme keguruan. Sebaliknya, semakin kecil konsep diri akademik maka semakin kecil pula ekspektasi kariernya sebagai guru sehingga berujung pada semakin kecilnya sikap profesionalisme keguruan.

Efek langsung yang signifikan dari minat keguruan terhadap sikap profesionalisme keguruan sebesar 0,1706 dengan kontribusi 21,34\% menunjukkan bahwa semakin besar minat keguruan maka semakin besar pula sikap profesionalisme keguruan. Sebaliknya, semakin kecil minat keguruan maka semakin kecil pula sikap profesionalisme keguruan. Selain itu, Efek tidak langsung yang signifikan dari minat keguruan terhadap sikap profesionalisme keguruan melalui ekspektasi karier sebagai guru sebesar 
0,2914 menunjukkan bahwa semakin besar minat keguruan maka semakin besar pula ekspektasi kariernya sebagai guru sehingga berujung pada semakin besarnya sikap profesionalisme keguruan. Sebaliknya, semakin kecil minat keguruan maka semakin kecil pula ekspektasi kariernya sebagai guru sehingga berujung pada semakin kecilnya sikap profesionalisme keguruan. Efek langsung yang signifikan dari konsep diri akademik terhadap ekspektasi karier sebagai guru sebesar 0,3709 dengan kontribusi $24,60 \%$, menunjukkan bahwa semakin besar konsep diri akademik maka semakin besar pula ekspektasi karier sebagai guru. Sebaliknya, semakin kecil konsep diri akademik maka semakin kecil pula ekspektasi karier sebagai guru. Efek langsung yang signifikan dari minat keguruan terhadap ekspektasi karier sebagai guru sebesar 0,2084 dengan kontribusi 18,57\%, menunjukkan bahwa semakin besar minat keguruan maka semakin besar pula ekspektasi karier sebagai guru. Sebaliknya, semakin kecil minat keguruan maka semakin kecil pula ekspektasi karier sebagai guru.

\section{Referensi}

Adnyana, I Ketut Ardiatmika. (2011). Determinasi Kepemimpinan Kepala Sekolah, Pelaksanaan Supervisi Akademik, dan Sikap Guru Terhadap Profesinya dengan Kinerja Guru Matematika SMP Negeri di Kabupaten Jembrana. Tesis (tidak diterbitkan). Singaraja: Universitas Pendidikan Ganesha.

Agustiani, Hendriati. (2009). Psikologi Perkembangan. Pendekatan Ekologi Kaitannya Dengan Konsep Diri Dan Penyesuaian Diri Pada remaja. Bandung: Refika Aditama.

Candiasa, I Made. (2010). Statistik Univariat dan Bivariat Disertai Aplikasi SPSS. Singaraja: Undiksha Press.

Dhanim \& Khairil H. (2010). Profesi Kependidikan. Bandung: Alfabeta.

Djaali, H. (2008). Psikologi Pendidikan. Jakarta: Bumi Aksara.

Hasbullah. (2006). Dasar-Dasar Ilmu Pendidikan. Jakarta: Raja Grafindo Persada.

Jahja, Yudrik. (2011). Psikologi Perkembangan. Jakarta: Kencana.

Koyan, I Wayan. (2012). Statistik pendidikan: Tehnik Analisis Data Kuantitatif. Singaraja: Universitas Pendidikan ganesha Press.

Pidarta, Made. (2007). Landasan Kependidikan: Stimulus Ilmu Pendidikan Bercorak Indonesia. Jakarta: Rineka Cipta.

Sarwono, Sarlito W. \& Meinarno, Eko A. (2009). Psikologi Sosial. Jakarta: Salemba Humanika.

Slamento. (2010). Belajar dan Faktor-faktor yang Mempengaruhinya. Jakarta: Rineka Cipta.

Soetjipto \& Raflis Kosasi.(2004). Profesi Keguruan. Jakarta: Rineka Cipta.

Srijanti, Purwanto S.K, \& Artiningrum, Pruni. (2006). Etika Membangun Sikap Profesionalisme Sarjana. Yogyakarta: Graha Ilmu.

Sudjana, Nana. (1989). Penilaian Hasil dan Proses Belajar Mengajar. Bandung: PT Remaja Rosdakarnya.

Sugiyono. 2012. Metode Penelitian Pendidikan. Pendekatan Kuantitatif, Kualitatif, dan R\&D. Bandung: Alfabeta.

Sujanto, Agus dkk. (2008). Psikologi Kepribadian. Jakarta: Bumi Aksara.

Sukardi. (2009). Metodologi Penelitian Pendidikan: Kompetensi dan Prakteknya. Cetakan ketujuh. Jakarta: Bumi Aksara.

Thorndike, Robert M. (1997). Measurement and Evaluation in Psychology and Education. Edisi ke lima. New Jersey: Prentice hall.

Undang-Undang Republik Indonesia nomor 20 tahun 2003 Tentang Sistem Pendidikan Nasional. 2003. Jakarta: Pemerintah Republik Indonesia.

Uno, Hamzah B. (2010). Perencanaan Pembelajaran. Cetakan ke-enam. Jakarta: Bumi Aksara. 